\title{
Challenges of Nikkei Peruvian Second Generation in Japan: An Overview of Their Employment Status after the Lehman Shock 2008
}

\author{
Jakeline Lagones ${ }^{1}$ \\ ${ }^{1}$ Graduate School of International Development, Nagoya University, Japan \\ Correspondence: Jakeline Lagones, Graduate School of International Development, Nagoya University, \\ Furo-cho, Chikusa-ku, Nagoya, 464-8601, Japan. E-mail: lurepi8@hotmail.com
}

Received: September 5, 2015

Accepted: September 14, 2015 Online Published: October 21, 2015

doi:10.5539/ass.v11n26p267

URL: http://dx.doi.org/10.5539/ass.v11n26p267

\begin{abstract}
This article analyzes the second generation of Nikkei Peruvians who are residing in Japan to overcome their employment status from the first generation of Nikkei unskilled workers. Using the mix methodology (Qualitative \& Quantitative) the paper describes the main characteristic of Nikkei Peruvian second generation after the financial crisis 2008, and focus in the main variables that influence their differences in employment status. The study involved the interview made since 2009 from the first generation Nikkei Peruvian to the second generation Nikkei Peruvian during 2015. They were asked to answer a socio-economic questionnaire and deep interview. Results of the study demonstrate that the main characteristics for Nikkei Peruvian second generation living in Japan are gender, civil status, place of birth, age group, study, social aid and employment status. Unlike the first generation unskilled workers the second generation employment status differs case by case due to their Japanese background. Even though some percentages of second generation continue as unskilled workers in Japanese factories even their social and human capital differs from the first generation of Nikkei Peruvian. The main differences between factory and no factory workers have to do with their civil status, age group, study status, and social aid. The second generation with background of two cultures and two languages who become unskilled workers means that their human and social capital as a bridge of two cultures will be devalued that would be consider by local government.
\end{abstract}

Keywords: Nikkeijin, employment status, second generation, foreign worker, Peruvian migrant

\section{Introduction}

\subsection{Background}

The Japanese law revised in the 1990s permitted to Nikkeijin enter and work in Japan (Ishi, 2008). "Nikkeijin references those who appear to be Japanese but may not behave like or specific Japanese (because they are the descendants of Japanese emigrants and were raised abroad)" (Yamashiro, 2008). One of the main group were Peruvians Nikkeijin who after enter to Japan, started to work as unskilled workers at the factories with very little upward mobility (Cornelius, Tsuda, \& Valdez, 2003). Foreign workers of Japanese ancestry can legally be employed in Japan as unskilled labor (Tanno, 2010; Nishi, 2008; Kondo, 2008). Most of them came with the contract employment by private agencies, these agencies provided to Nikkei Peruvians helped to be accommodate in Japan. Therefore they did not need to use Japanese language at all for survive in Japan. As a consequence Nikkei Peruvians did not think too serious about Japanese language, they could not imagine how difficult would be in their future to be integrated in Japanese society.

The global financial crisis, the globalization and the great Japan earthquake cause the labor transformation after the Lehman Shock in Japan (Takashi, 2013). Peruvians who stay in Japan have to challenge with this labor transformation too. The situation was difficult from Nikkei first generation because they did not have the agency companies to help them as in the past, so, many of them lost their jobs and then it was more difficult for them to look for a new job with low or no Japanese ability. As a result they have to move from their places looking for a new job with their family. The other problem was the education of their children, because there is not any special programs for helping Peruvians children education, children have to attend lessons in Japanese even they could not understand Japanese language, so the problem of language learning process became the principal issue for children education, they could not maintain the mother tongue in a good level and they could not learn Japanese good level either as a consequence, it will become a limitation for second generation to choose their employment 
status in Japanese society, even they grow up in Japan. On the other hand the first generation did not want their children second generation to do the same unskilled job in Japan.

The first generation of Nikkei has been investigated by many researchers (Takenaka, 2012; Tano 2010; Hiromi 1996; Yamanaka, 1993). In recent years, there has been an increasing interest in education of second generation of Nikkei in Japan (Brody, 2002; Sueyoshi, 2014). Sueyoshi studies have primarily concentrate on educational and Professional careers of Nikkei second generation, her results demonstrated that foreign parents are not involved at all in their children education to understand that the Japanese language limitation is one of the consequence to performance into the Japanese educational system and to improve their mother tongue become assets to enter at the job market in Japan (Sueyoshi, 2014). But there is no data regarding the employment status of second generation especially after the world crisis 2008. Therefore this study aims to describe the main characteristics of second young generation to reside in Japanese society after the financial crisis and to find the main variables that influence the differences in employment status of second young generation of Nikkei Peruvian.

\subsection{Research Statement, Objective and Questions}

During Lehman Shock the Japanese government prepare some programs to help the unemployment situation in Japan, most of the program benefit to one group of Nikkei Peruvian second generation who lost their jobs and were enrolled in these programs, the other group have to use different strategies to overcome their tertiary education and the last group is the heterogeneous group who use other strategies to maintain their employment status in Japan. However, an empirical research for this issue is not yet available to explore what kind of strategies these different groups used to overcome the world crisis and what is the situation of their employment status in Japan for the Peruvian Nikkei second generation after the Lehman Shock. To that end, the study utilized survey, micro ethnographic research with deep interview and the Chi-square Test to answer the following questions; first; what are the main characteristics for second young generation of Nikkei Peruvian to reside in Japanese Society after the financial crisis? And second: which are the main variables that influences in employment status in the second young generation of Nikkei Peruvian? This means how those problems explain above were overcome by Nikkei Peruvian second generation and how are they living in Japan. This paper will be implemented in the following way: section 2 describes the second generation Nikkei Peruvian relevant problems in Japan, especially focus in education, identity, social, and employment problem; section 3 describes the methodology; sections 4 and 5 interpret the qualitative and quantitative analysis; section 6 explains the results and discussions; and the last section presents the conclusion.

\section{Nikkei Peruvian Second Generation}

\subsection{The Development of Language and Education of Nikkei Young People of Second Generation}

\subsubsection{Language}

After the first generation of Nikkei Peruvian arrived in Japan in 1990, it had been two and half decades. While they were living in Japan they decided to bring their family included their children. Their spouses usually started to work at the Japanese factories, but the problem started for them, when their children have to attend Japanese schools. "...Peruvians still have a little interaction with Japanese society, partly due to language and culture barriers and partly due to their marginal position on the job market" (Karsten, 2010, p. 69) Therefore, Japan is not prepare at all for foreign residents. Japanese school law accept any foreign children to enter the elementary and junior high school as Japanese children do, but all the lessons are taught only in Japanese. Foreign children who start to study at Japanese school at their early age can overcome the language easy in a few years. On the contrary, those foreign children who already started their education in their country have difficult to assimilate the Japanese education system, especially because of their difficult for learning Japanese language.

Then, Nikkei second young generation could not maintain the mother tongue in a good level and they could not learn Japanese at good level either. Peruvian children who enter Japan in the early age started to have a language problem in their houses to communicate with their parents, because they are speaking in Spanish at home with parents and talking in Japanese at Japanese school. As a result, students cannot communicate very well in Spanish with parents and sometimes cannot have good communication at school in Japanese either, because they did not receive any support in home with Japanese language. Consequently, Nikkei second young generation have to challenge these problems by their selves.

The principal reason that Nikkei Peruvian first generation came to Japan was for working at the factories. In consequence, the majority of Nikkei Peruvian people work many hours at job and they do not have enough time for learning Japanese and help to their children. On the other hand they do not assimilate the importance for 
children to learn Spanish until they have communication trouble in house. Nikkei Peruvians do not understand the importance of supporting their children in learning Spanish and Japanese language. Fortunately this situation was not in all families, some Nikkei families attended some Japanese lessons, especially during the world crisis 2008 (Lehman Shock). During this period the Japanese government offered some Japanese lessons and technical courses as a program for unemployment people. This program helped some families to be involved in Japanese courses, therefore some second generation children received some support from their parents.

As conclusion, some second generation Nikkei Peruvians who received the support of their parents could go for tertiary education, the other group could not attend tertiary education in Japan, and other percentage of them could not finished the high school either. To settle in Japan and become accepted in Japanese society, foreign residents of Japanese descent need to acquire Japanese language skills as the means of communication in Japanese society and for their children it is necessary to maintain the Spanish as the mother tongue as the possibility of returning to the home country in the future. Lack of Japanese-language limited in different aspects their life in Japan, including child education, employment, and communication with government offices and with Japanese neighbor.

\subsubsection{Education}

The education development and its connection with the labor market for the Peruvian Nikkei second generation it's an important point to be analyzed, for understanding the characteristics of second generation Peruvian Nikkei in Japan. Ana Sueyoshi, in her research "Second Generation of South Americans in Japan: Building Educational and Professional Career" found that "there is a group of conspicuous but unfortunately still few unexpected achievers, whose educational attainments have not always been singled out by the current literature. This second generation of South Americans is building their educational and professional careers in Japan or in their homeland" (Sueyoshi, 2014).

Sueyoshi examined her result by interviewing 24 Latin American second young generation who are studying or working in the Kanto area, to identify the main common determinants in continuing high school and post-secondary education. Most of her interviewer were students at high school or university who succeeded the barriers of the language by using different strategies of Japanese system education (letter of recommendation, interview). But what happen with those who could not overcome the barrier of the language, who did not have the support of their parents and who lost the motivation to go for tertiary education. It is difficult to determine from the total population of young second generation of Peruvian in Japan, but it is important to know both parts the failure and successful cases who continue or not their education in Japan; to finally understand; what are their background to have differences in employment status within the labor market in Japan.

\subsubsection{Identity Problem}

Nikkei Peruvian children who stayed living in Japan with their parents have different background they are heterogeneous group. It means that some of them came at their early age, other at elementary school age and the most difficult group came at junior high school age. Therefore the situation of each one are very different and the problematic of each of them too. Nikkei Peruvian Children had new challenge when they went to Japanese school while their parents worked at the factories. But, parents do not need to use the Japanese language as their children, who have to challenge with the new Japanese society at school; most of them never traveled to Peru, but they are Peruvian, most of them cannot speak Spanish as their native language but they are Peruvian native speakers, as a consequence; they feel confusing about their identity too.

During the interview that I did to Nikkei Peruvian second generation who grow up in Japan, I found that some of them feel confusing about their identity. Many Peruvians children who grow up in Japan attending Japanese schools from early age think that they are Japanese. Some of them feel confusing when they have to talk about their family background and the other group feel just they are different from Peruvians. However, when they become adult and they have to decide between Peruvian or Japanese nationality they feel more confusing. One of the big problems is the question that sometimes they ask by their selves: who am I? Am I Japanese? Am I Peruvian? Am I half? Which is my country? Different questions that make them confuse about their identity and citizenship.

On the other hand, some of them nationalized as Japanese. Nevertheless one of the interviewer told me that when he applied for a job in Japanese company, they separated him from the Japanese group and considered him as a "Japanese naturalized abroad". Therefore even Nikkei Peruvian second generation speak fluently Japanese, study at Japanese school, his physical appearance is like Japanese, and grow up all their life in Japan they will never feel as a Japanese in Japan, because of their foreign background. As Robert Moorehead affirmed that "The youth report a range of identities (hâfu, Nikkei, Peruvian, Japanese, Japanese+Peruvian), but they struggle to articulate 
how being Peruvian is a part of their daily lives. Instead, a Peruvian identity is symbolic, reduced to expression in birthday cakes, Christmas dinners, and occasionally speaking Spanish" (Moorehead, 2014). Many reasons are pushing the Young second generation to assimilate the Japanese society, as I mentioned before, one is the Japanese system education which obligated them to overcome the language limitation if they want to go to tertiary education.

\subsection{Nikkei Second Generation Employment Status Problem in the Labor Market in Japan}

The Second young generation of Nikkei Peruvian, become divided in two groups. First the succeeded group who overcame the barrier of the language and continued high school or tertiary education and second group formed by the young Nikkei Peruvians who did not finish high school or tertiary education. As a consequence, their differences in employment status depend on which group they belonged to. Before the Lehman shock 2008, most of the second group were working as part time job or full time workers at factories, and the second group studying or working in Japanese companies as "SALARY MAN" (office workers). Most of the Peruvian first and Nikkei Peruvian second generation has a contract job (KEIYAKUSHAIN), not permanent job (SEISHAIN), therefore, many of them lost their jobs during the world crisis, and especially those who worked at the factories, due to many companies stopped their production in manufacture. What happened with the second generation Nikkei Peruvian in Japan after this period of time? For Peruvian Nikkei second with their Japanese background, their future is staying in Japan. Many second generation also compare the salary of their parents working at the factory (Blue collar workers) with the salary of salaryman after studying at the university (White collar workers) and some group realized that to earn more money it is better to work at the factory. In Peru this situation is opposite, if people want to earn more money, they have to study at the university because working at the factories, in Peru it means earning salary only for surviving.

\subsection{Lehman Shock and Its Consequences in Nikkei Peruvian Second Generation as Labor Force in Japan}

Regarding to the study of Takenaka in 2009, the generational succession, would be one mechanism to change Peruvian Nikkei First Generation low social status at Japan to upward mobility. But now many years later and after a world crisis happened (Lehman Shock), Nikkei Peruvian second generation did not cover at all the perspective of the first generation. In addition Takashi Moriya (2013) affirmed that "the middle-class is collapsing even in Japan, and with an increase in non-regular employees as a result of the changes in human resource management and labor after the Lehman Shock". This problem also affected Nikkei Peruvian second generation considering that the recruitment of new graduates in 2012 was extremely low in Japan. In addition Moriya showed that "The Great East Japan Earthquake has further increased unemployment of a large number of young people. As a result of continued high unemployment, after the Lehman Shock, 1.93 million people received Japan's welfare benefits in August 2010. There is increased participation by the NPO's or social enterprises in dealing with poverty issues. (Moriya, 2013)

Takashi also indicated that the three major causes of the labor transformation after the Lehman Shock in Japan are (in that order): 1. the global financial, 2. The Great East Japan Earthquake, which caused widespread devastation and destroyed several business units across Japan. 3. "Globalization", which was particularly exposed after the Lehman Shock. (Takashi, 2013) "The people most affected by the Lehman Shock in the fall were foreign workers in non-regular employment. In Japan, low-skilled foreign workers are legally not permitted." (Moriya, 2013) As a result, not only the global financial crisis, but also the globalization and the great east Japan earthquake causes the labor transformation after the Lehman Shock in Japan. Therefore, Regarding to the literature review the Nikkei Peruvian immigrant family and the important variables for second generation Nikkei Peruvian settled in Japan, are main points for research to understand the characteristics of second young generation of Nikkei Peruvian and their differences in employment status especially during the labor transformation in Japan after the Lehman shock.

\section{Methods}

Qualitative methods, which are used more often in anthropological research, can provide descriptive and analytical explanation to a single phenomenon, like Nikkei Peruvian second generation family. It consisted in a micro ethnographic research in deep interviews with Nikkei Peruvians second generation who live in Japan. As is usual ethnography method refers to fieldwork, in this case I made a fieldwork in Japan especially in the places where most of Nikkei are living with their families. Therefore I try to live with them, participating in many activities. I also used the Chi-square Test because it is used to determine whether there are statistically significant differences between expected and observed frequencies in categorical variable. It helped me identify effective differences, which are not due random sampling variation. 


\subsection{Interview in Aichi Prefecture (2009-2015)}

I have been interviewing Nikkei Peruvian since 2009 researching Nikkei Peruvian first generation using the micro ethnographic research, this experience helped me to connect and meet with Nikkei Peruvian second generation with who I continued interviewing between January and June 2015, in the Aichi Prefecture area. "Aichi Prefecture has the highest number of foreign workers of all the Japanese prefectures as well as the highest number of Nikkei workers" (Brody, 2002, p. 59). The interview was made in Spanish and sometimes in Japanese for those second generation who cannot understand Spanish very well. Kanto-area concentrates most of the Nikkei Peruvian families after Tokyo and Osaka, because most of the manufacture industry are located in these cities. I interviewed about 33 Nikkei Peruvian young generation and some official public workers in two different cities who are working several years as a translator helping Nikkei Peruvian first and second generation.

\subsection{Data Collection}

The data collection method was one interview questionnaire survey, observations and deep interviews. The objective was to describe the main characteristic of second young generation of Nikkei Peruvians to reside in Japanese society after the financial crisis and to find the main variables that influence the differences in employment status of second young generation of Nikkei Peruvian. The exploration of the data base was based on various types of analytical approaches: Descriptive, exploratory and interpretative. After obtained the main variables from the ethnographic research, I made a statistical analysis to observe the differences of these variables with employment status and to support this result, I used the Chi-square test to prove if these differences are statistically significant.

\subsection{Data Description}

The interviewers were 33, some of them were born in Japan, other came in their early age, another group came to Japan at elementary school age and the final group came at junior high school age. Each group has different background in their education. Therefore, it measures the difficult in learning Japanese language regarding to what age they had at the moment of arrival to Japan. On the other hand, they can speak Spanish as a mother tongue and while they continue their studies in Japan some of them learned Portuguese, Japanese, and English. But for some of them, their level in all those language are not well, because they could not learned the all process of learning language (listening, speaking, writing and reading) most of them can speak but writing and reading even in their mother tongue was not complete at schools at all. Most of them have Peruvian parents and a little percentage Japanese father or mother.

\subsection{Empirical Analysis: Chi-Square Test}

In Qualitative method I used the two ways tabulation between the dependent variable (employment status) and the independent variable (age, social aid, education, marital status, place of birth and gender)

\subsection{Variables under Study}

A statistical analysis of employment status is performed using six relevant variables from the microethnographic case study: (1) Gender, (2) Civil Status (3) Place of birth (4) Age group (5) Study Status (6) Social Aid.

\section{Quantitative Analysis}

\subsection{Tabulation of Variables}

\subsubsection{Gender}

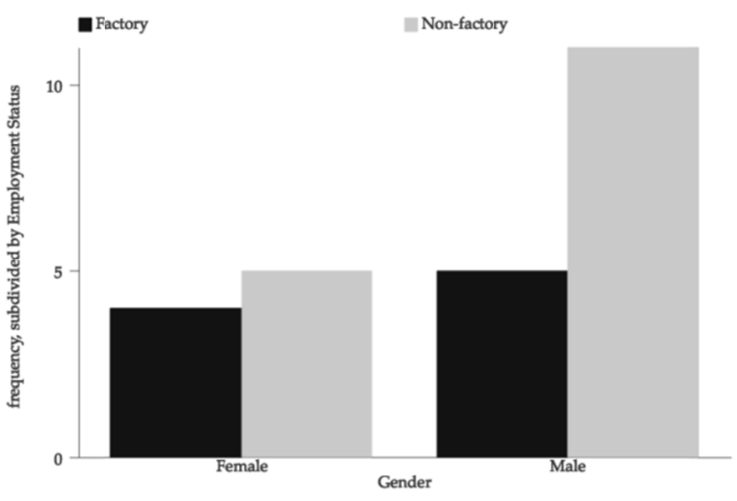

Figure 1. Interpretation of the variable gender 
Most women and men have no factory jobs. Regarding to my interview 44\% of women Nikkei second generation works in the factory and $56 \%$ are not working in the factory. On the other hand $31 \%$ of men are working in the factory and $69 \%$ are not working in the factory. Thus there are observed differences. But are these differences statistically significate? To answer this question in the next section I will use a Chi-square test.

\subsubsection{Civil Status}

Between employment status and civil status first in my sample people who work in factory (56\%) are single and $(44 \%)$ are single no factory workers. whereas marry and divorce work somewhere else.

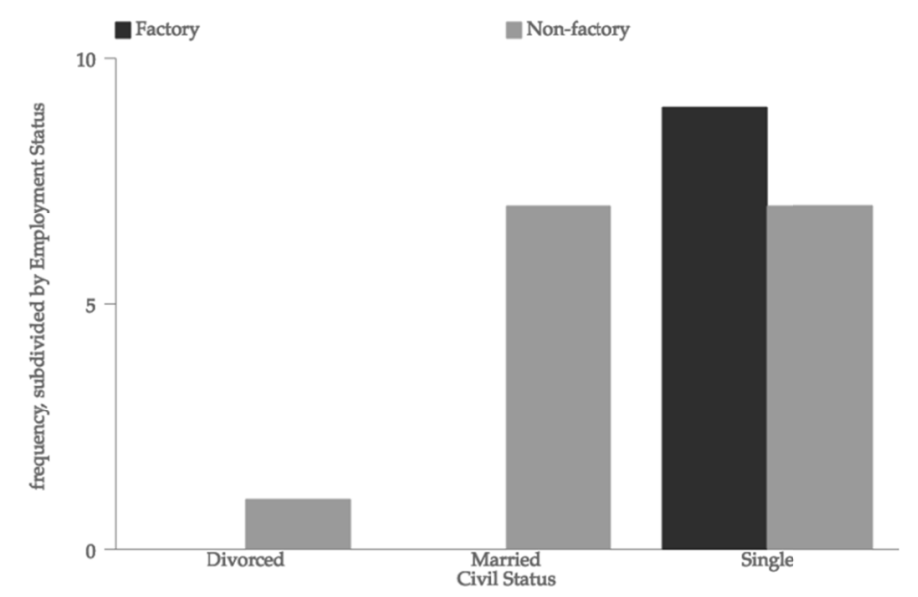

Figure 2. Interpretation of the variable Civil Status

\subsubsection{Place of Birth}

Between employment status and place of birth. Most of the people second generation who were born in Peru are not working in the factory $(67 \%)$ but $33 \%$ continue working in the factory. The other group of the people who were born in Japan, $50 \%$ of them continue working in the factory.

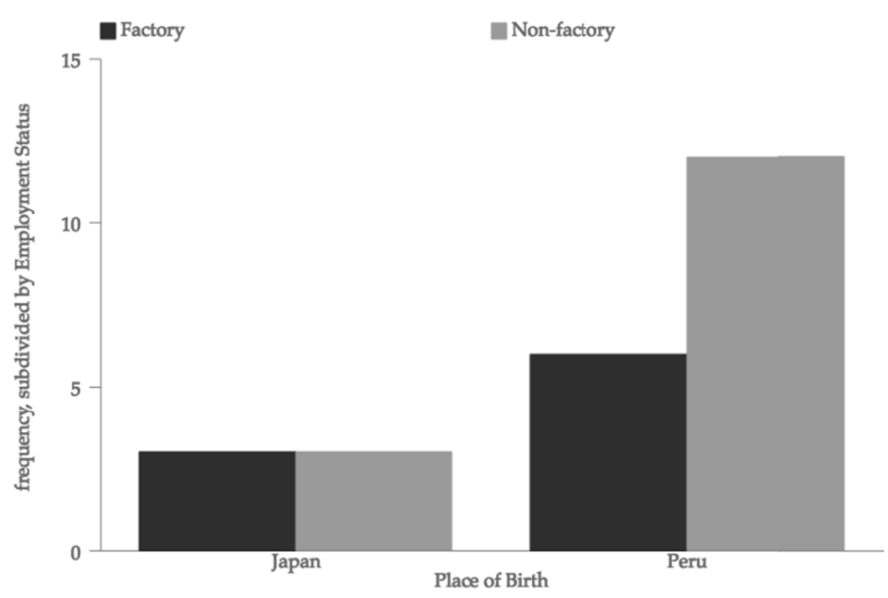

Figure 3. Interpretation of the variable Place of birth by data tabulation

\subsubsection{Age Group}

This is a two way tabulation between employment status and age group. Most people of second Nikkei generation between 21 1nd 30 years old (64\%) are not working in the factory but the other group about $37 \%$ continue working in the factory. People between 15 and 20 years old are working in the factory, maybe most of them dropped out the school. And people between 31 and 40 years old are not working in the factory, some of them have their own business, or they are fleeter. Thus there are observed differences that later I will show if these differences are statistically significant. 


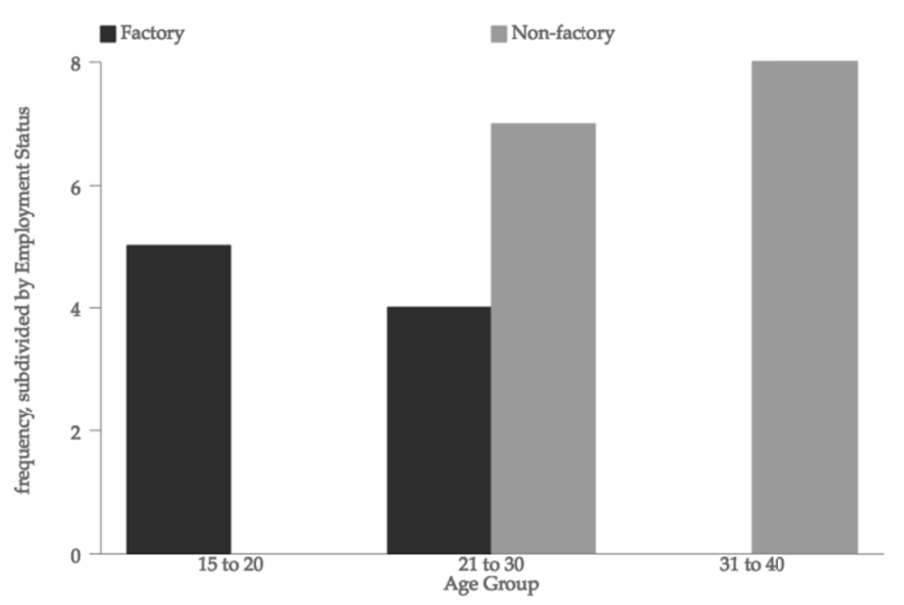

Figure 4. Interpretation of the variable Age group by data tabulation

\subsubsection{Student Status}

Between employment status and student status from my interview group, people who do not study are in total $80 \%$ and people who study are $20 \%$. Most of the people who do not study $(75 \%)$ are not working in the factory and only $25 \%$ of the people who does not study work in the factory.

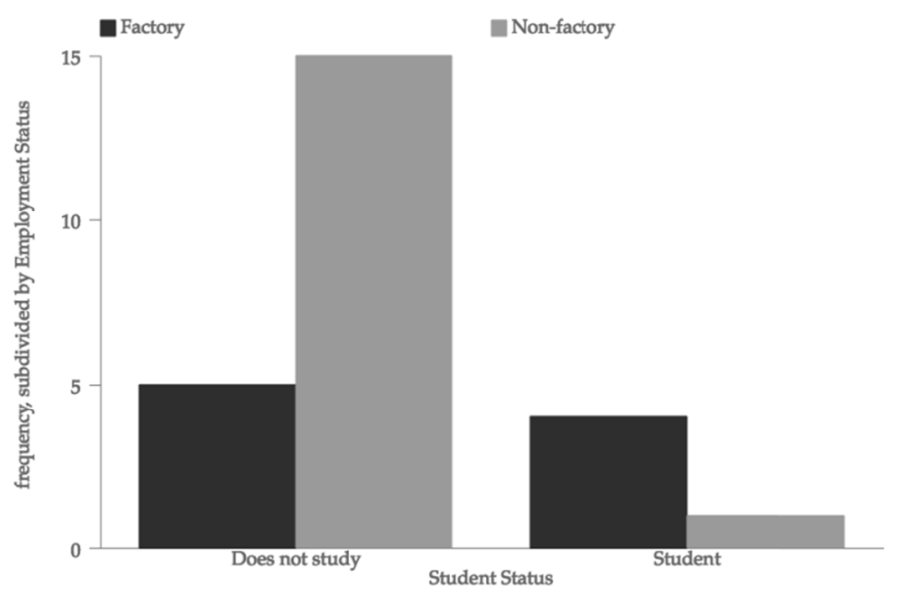

Figure 5. Interpretation of the variable Student Status by data tabulation

\subsubsection{Social Aid}

This is a two way tabulation between employment status and social Aid. Most of the people who are not in the factory received more social Aid as the benefit from the government.

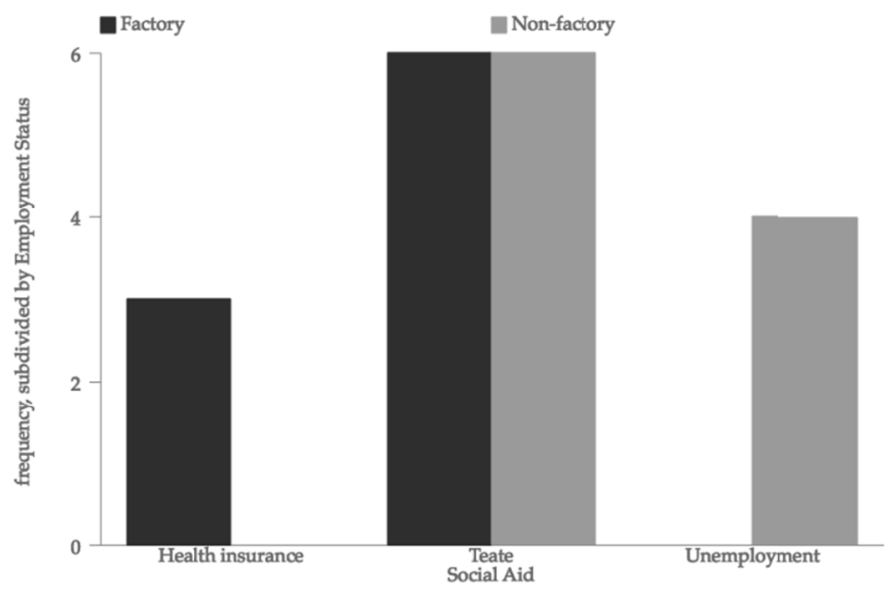

Figure 6. Interpretation of the variable Social Aid by data tabulation 
After performed the statistical analysis of employment status, using the six relevant variables: (1) Gender, (2) Civil Status (3) Place of birth (4) Age group (5) Study Status (6) Social aid that I found from the micro-ethnographic research. I observed some differences but to support this result I used the Chi-square test to prove if these differences are statistically significant.

Table 1. Q-square Test 2015

\begin{tabular}{|c|c|c|c|c|c|}
\hline \multirow{3}{*}{ Characteristics } & \multicolumn{4}{|c|}{ Employment Status } & \multirow{3}{*}{$\begin{array}{l}\text { Chi-Square } \\
\text { Significance }\end{array}$} \\
\hline & \multicolumn{2}{|c|}{ Factory Work } & \multicolumn{2}{|c|}{ Non Factory Work } & \\
\hline & Number & Percentage & Number & Percentage & \\
\hline \multicolumn{6}{|l|}{ Gender } \\
\hline Female & 4 & $44 \%$ & 5 & $31 \%$ & 0.4352 \\
\hline Male & 5 & $56 \%$ & 11 & $69 \%$ & $\operatorname{Pr}=0.509$ \\
\hline Total & 9 & $100 \%$ & 16 & $100 \%$ & \\
\hline \multicolumn{6}{|l|}{ Civil Status } \\
\hline Divorced & 0 & $0 \%$ & 1 & $7 \%$ & 7.2 \\
\hline Married & 0 & $0 \%$ & 7 & $47 \%$ & $\operatorname{Pr}=0.027$ \\
\hline Single & 9 & $100 \%$ & 7 & $47 \%$ & \\
\hline Total & 9 & $100 \%$ & 15 & $100 \%$ & \\
\hline \multicolumn{6}{|l|}{ Place of Birth } \\
\hline Japan & 3 & $33 \%$ & 3 & $20 \%$ & 0.5333 \\
\hline Peru & 6 & $67 \%$ & 12 & $80 \%$ & $\operatorname{Pr}=0.465$ \\
\hline Total & 9 & $100 \%$ & 15 & $100 \%$ & \\
\hline \multicolumn{6}{|l|}{ Age Group } \\
\hline 15 to 20 & 5 & $56 \%$ & 0 & $0 \%$ & 13.1394 \\
\hline 21 to 30 & 4 & $44 \%$ & 7 & $47 \%$ & $\operatorname{Pr}=0.001$ \\
\hline 31 to 40 & 0 & $0 \%$ & 8 & $53 \%$ & \\
\hline Total & 9 & $100 \%$ & 15 & $100 \%$ & \\
\hline \multicolumn{6}{|l|}{ Study Status } \\
\hline Does not study & 5 & $56 \%$ & 15 & $94 \%$ & 5.2517 \\
\hline Study & 4 & $44 \%$ & 1 & $6 \%$ & $\operatorname{Pr}=0.022$ \\
\hline Total & 9 & $100 \%$ & 16 & $100 \%$ & \\
\hline \multicolumn{6}{|l|}{ Social Aid } \\
\hline Health Insurance & 3 & $33 \%$ & 0 & $0 \%$ & 6.9667 \\
\hline Teate & 6 & $67 \%$ & 6 & $60 \%$ & $\operatorname{Pr}=0.031$ \\
\hline Unemployment Insur. & 0 & $0 \%$ & 4 & $40 \%$ & \\
\hline Total & 9 & $100 \%$ & 10 & $100 \%$ & \\
\hline
\end{tabular}

Source: author's field survey.

\subsection{Significant Differences between Variables: The Chi-Square Test}

Table 1 reports that there are significant differences between factory and non-factory workers. In particular, the Chi-square test shows that the main differences between these two groups have to do with their civil status, age group, study status, and social aid. On the other hand, differences in gender and place of birth do not show significant over employment status. (1) For gender : if the P value is less than $5 \%$ then the differences in gender explain the differences in employment status but in my case the $\mathrm{P}$ value is $50 \%$ thus the differences in gender do 
not explain employment status. (2) For civil status: $\mathrm{P}$ value is $2.7 \%$ thus differences in civil status explain differences in employment status. (3) For place of birth: the $\mathrm{P}$ value is $46.5 \%$ thus differences in place of birth do not explain differences in employment status. (4) For age group: the P value is $0.1 \%$ thus differences in age group explain differences in employment status. (5) For study status: the P value is $2.2 \%$ thus differences in study status explain differences in employment status. (6) For social Aid: the P value is $3.1 \%$ thus differences in social aid explain differences in employment status.

\section{Qualitative Analysis}

The data collection method was one interview questionnaire survey, observations and deep interviews, prepared by the research. The objective was to describe the main characteristic of Nikkei Peruvian second generation to reside in Japanese society after the financial crisis and to find the main variables that influence the differences in employment status of Nikkei Peruvian second generation. The exploration of the data base was based on various types of analytical approaches: Descriptive, exploratory and interpretative. I also used the Chi-square Test.

\subsection{Categorization Result from the Interview 2015 from Nikkei Peruvian Second Young Generation}

The interviewers were classified in seven typologies groups:

Table 2. Typologies of Nikkei Peruvian Second Generation

\begin{tabular}{|c|c|}
\hline Typology & Description \\
\hline 1 & Second young generation who was born in Japan. \\
\hline 2 & Second generation who came to Japan in their early age $(1,2,3,4,5,6$ years old $)$ \\
\hline 3 & $\begin{array}{l}\text { Second generation who came to Japan when they were at early elementary school }(1,2,3 \text {, } \\
\text { grade).Their age are between } 7,8,9 \text { years old. }\end{array}$ \\
\hline 4 & $\begin{array}{l}\text { Second generation who came to Japan when they were at } 4,5,6 \text { grade (between } 10,11,12 \text {, years } \\
\text { old) }\end{array}$ \\
\hline 5 & $\begin{array}{l}\text { Second generation who came to Japan when they were in Junior high school } \\
(13,14,15 \text { years old })\end{array}$ \\
\hline 6 & Second generation when they were in high school $(16,17$ years old $)$ \\
\hline 7 & Second generation who made u-return between Japan and Peru \\
\hline
\end{tabular}

\subsection{Qualitative Results}

The findings from this study suggest that the main characteristics variables for Nikkei Peruvian second generation living in japan are gender, civil status, place of birth, age group, study, social aid and employment status. Regarding to the main variables that influence the differences in employment status in the Nikkei Peruvian second generation this study found that there are significant differences between factory and non-factory workers. In particular, the Chi-square test shows that the main differences between these two groups have to do with their civil status, age group, study status, and social aid. On the other hand, differences in gender and place of birth do not (significantly) explain differences in employment status.

\subsubsection{Gender}

Both results show that it does not affect the employment status, both men and women have the same right to obtain a job wherever they plan and choose. But, I have to mention that the difference in salary exist between men and women especially in the factories. Some interviewers said that "Men can earn more salary per hour than women because they can do hard jobs and of course more dangerous job. I prefer to work in "OBENTO" (FOOD FACTORY), even the salary is low it is cleaner job and not dangerous" another interviewer said "My boyfriend can earn 1,200 yens per hour but I received 950 yens per hour working at the factory". As the interviewer mentioned, men can earn more at the factories but regarding to the office worker they earn according to their academic background.

\subsubsection{Civil Status}

Regarding to observation and deep interview to Nikkei Peruvian second generation who works in factory are 
single whereas marry and divorce are not working in factory.

\subsubsection{Place of Birth}

Nikkei Peruvian second generation regarding to their place of birth are divided in two groups, the first who was born in Japan and the second who was born in Peru. This difference does not influence in their employment status because even the group who was born in Japan are working in the factory unless they grow up in Japan and their ability with Japanese language is better than the second group.

\subsubsection{Age Group}

Some Nikkei Peruvian second generation who came to Japan at their early age (Typology 2) are not working at the factory, and some of the other group who came to Japan later are working at the factory. And the others are using different strategies of studies to overcome the language barrier limitation and low level scores to continue tertiary education.

\subsubsection{Student Status}

The observation and deep interview suggest that Nikkei Peruvian second generation who studied tertiary education used different strategies to overcome the different barriers case by case regarding to the 7 typologies that I classified. Strategy 1: students with low Japanese level, return their country then after finished their basic education return to Japan and enter to junior high school while studying Japanese at "JUKUS "or at school (Typology 7). Strategy 2: students who were born in Japan and decided to study Spanish language as a career during their university studies made a short return to their country to improve their Spanish and as a result when they apply for job hunting in Japan have one more advantage to obtain a job. (Typology 1). Strategy 3: student with low Japanese who came at 10, 11, and 12 goes to low level high school or technical high school. After finishing high school they continued their studies at "SENMONGAKO "9 (technical school) (Typology 4). Strategy 4: students who came at high school level, studied English as a second language in their country. Therefore, coming to Japan use their high score in "TOEIC" test to enter the university even they cannot manage well Japanese because of their short time in Japan (Typology 7). Strategy 5: some young second generation who were born in Japan (typology 1) enter low level university and study business after that they work as a seller. For example selling insurance health plan. Therefore they use their Spanish ability to enter the Spanish speaker community. This strategy helps those people to improve and maintain their status employment. Strategy 6: on the other hand, some Nikkei Peruvian second generation during the world crisis (Lehman Shock) took advantage studying technical career as the Japanese government offered during the crisis for unemployment people. Some of them studied Japanese course, computer, home helper, web design, aromatherapy and other technical career while receiving a percentage of salary because of their unemployment condition.

\subsubsection{Social Aid}

Just all the interviewers received some aid from the Japanese government, especially the aid called "Jidou Teate Nintei Seikyu Sho. This kind of government aid helped the family to alleviate the economic burden of the children.

\section{Discussion}

The findings from this study suggest that the main characteristics variables for Nikkei Peruvian second generation living in Japan are gender, civil status, place of birth, age group, study, social aid and employment status. Regarding to the main variables that influence the differences in employment status in the Nikkei Peruvian second generation, this study found that there were significant differences between factory and non-factory workers. In particular, the Chi-square test showed that the main differences between these two groups had to do with their civil status, age group, study status, and social aid. On the other hand, differences in gender and place of birth do not (significantly) explain differences in employment status.

\subsection{Civil Status}

First in my sample people who work in factory are single whereas marry and divorce work somewhere else. This result also has statistical differences in the Chi-square test between employment status and civil status.

\subsection{Employment}

Most of Nikkei Peruvian second generation are not doing the same job as first generation who came to Japan in the 1990s, (factory workers) the second generation has different typologies compare to the first generation. Nikkei Peruvian second generation has higher social and human capital than first generation because they grow up in Japan. Therefore, some of them are working in different types of job like office workers, micro entrepreneurs, restaurants, shops and some of them became university students. On the other hand, somewhat 
surprisingly is that some percentage of them are doing the same job as first generation (factory workers) even they have better social and human capital. The findings of this study regarding the employment variable can be summarized in the next figure.

Table 3. Employment status

\begin{tabular}{ccccc}
\hline Employment Status in Japan & Meaning & Factory & No factory & Main requirements \\
\hline Shain (Seishain) & Permanent Job (direct) & Yes & Yes & Language \\
Keiyakushain & Contract Job (direct) & Yes & Yes & Language \\
Hakenshain & Job by contract \& intermediary & Yes & Yes & Intermediary person \\
Arubaito & Part time job per hours & Yes & Yes & Language \\
Fleeter & Change constantly their job & Yes & Yes & Language \\
\hline
\end{tabular}

\subsection{Social Aid}

During the interviews just $100 \%$ of the Nikkei Peruvian second generation affirmed that they received at least one of social aid from Japanese government, for example: the "Jidou Teate Nintei Seikyu Sho" : this means that the parents of children aged 15 years or under can receive "Child Allow". The monthly stipend changes according to the age of the child, the order of births of the child, and the income of the guardians. Children under 3 -years-old receive 15,000 yen per month from Japanese government; over 3-years-old and prior to elementary school graduation receive 10,000 yen per month for first and second children; 15,000 yen per month for third and subsequent children and Junior high school students receive 10,000 yen per month.

In addition, in Aichi Prefecture for example they can receive also other types of aid: (1) Accident Insurance which include workmen accident and compensation insurance. (2) Employment and unemployment insurance which included benefits for elderly people. (3) Employment benefit for elderly: child care benefits and family care benefits. (4) Educational: school expenses subsidy system and high school tuition support found. (5) Scholarship: student scholarship loans for high school students and for two years College, vocational and University Students scholarship by (JASSO). (6) Medical insurance: employment health insurance and national health insurance. (7) Public pension system: national pension, employees' pension insurance and mutual aid pension. (8) Single parent household benefit: child rearing allowance, Aichi orphan allowance and Medical System for Single Parent Household. (9) Public houses which included prefectural, municipality and Urban Renaissance Agency. (Aichi hand book, 2015).

\subsection{Study}

According to the investigation by Sueyoshi "In spite of being stigmatized as academic underachievers, a conspicuous but unfortunately still limited second generation of south Americans are building their professional careers in Japan or in their homeland" (Sueyoshi, 2014, p. 126). This result also found that only small group of second generation continued tertiary education. On the other hand my result showed that many Nikkei Peruvian second generations do not have too much motivation to continue studying at university, professional or technical schools even they do not have the language barrier. One of the reason is as one of them explain that: "even if I go to the university finally my salary will be equal or less than factory workers" Unless they work in a big company, because in Japan the successful student who went to the high level university will work in a big and successful company. Going to the university in Japan does not mean that they will find a job in their major or the job they desire to work, it depends on the job hunting and from which university they will graduate. In the case of Peru there is no job hunting process as well as Japan, after graduation students have to find a job by their selves, university does not support with this process.

\subsection{Age}

In the two way tabulation between employment status and age group most people between 21 and 30 years old are not working in the factory but the other group about $36 \%$ continues working in the factory. This difference in the Chi-square test demonstrated also that there are statistical differences between age group and employment status. In the ethnographic research I observed that some young people ( 25 years old) who are working in the factory as a "HAKENSHAIN" said: "I was working as a "SHAIN" but I felt discrimination because I was obligated to work more hours, extra hours without extra salary and I felt the company prefer the Japanese because they are more year working there..." to corroborate this feeling I asked some Japanese people who had 
the same experience, but the feeling is different even the situation is the same. One of the interviewer; a Japanese woman told me that working as a "SHAIN" is very hard not only for foreign people also for Japanese people. Therefore, to obtain a better job as a "SHAIN"; she decided to retire from the hard job; and she enter at graduate school. As a result, I can say that the way how some Nikkei Peruvian second generation think compare to Japanese is different but the treatment at job is the same. Some Nikkei Peruvian second generations think that to obtain more money it is not necessary to become "SHAIN" and to endure the Japanese hard system at those jobs. Next graph shows the summary of the result that I interviewed to a Japanese woman worker as a "SHAIN".

Table 5. Japanese salary man working hours

\begin{tabular}{ll}
\hline \multicolumn{1}{c}{ Feature } & \multicolumn{1}{c}{ Description } \\
\hline Interview sample & Japanese salaryman 2015 \\
(a Japanese person) & Literature \\
University & 6 interviews before obtain the job \\
Job Hunting & Wedding company \\
Job & Shain \\
Type of Job & 2 months \\
Training & 220,000 yens \\
Salary & Monday through Friday working 12 hours \\
Hours working & Saturday and Sunday 17 hours \\
Extra hours & No payment \\
Extra hours & \\
\hline
\end{tabular}

The findings provide evidence that, working as a "SHAIN" in Japan is very hard in some companies as a part of the system not only for foreign people as well as for Japanese too.

The most striking result to emerge from the data is that, during the Lehman shock some unemployment young second generation took advantage of the technical studies. Because the Japanese government offered technical courses during the crisis for unemployment people. Some of them studied Japanese course, computer, home helper, web design, aromatherapy and other technical career.

\section{Conclusion}

To answer question one: What are the main Characteristics for second generation of Nikkei Peruvian to reside in Japanese society after the financial crisis? This study used an ethnographic research as a descriptive analyzes, using observation, deep interviews and surveys for Nikkei Peruvian second generation after the world crisis. The results showed that the main characteristics for Nikkei Peruvian second generation living in Japan were gender, civil status, place of birth, age group, study, social aid and employment status. Where civil status and age variables are similar to the first generation. The most relevant here is the employment status because regarding to the first generation the employment status for just all of them were as unskilled factory workers. However, the results of this article suggest that Nikkei Peruvian second generation employment status differs case by case. Therefore, some percentages of them are doing the same job as the first generation; working at the factory; even their social and human capital are better than the first generation. Unlike the first generation; Most of them are not working as a HAKENSAHIN, because they studied and grew up in Japan; and they can manage at least two languages (Japanese and Spanish) most of them do not need the intermediary as their parents needed.

To answer question two: Which are the main variables that influence the differences in employment status in the second young generation of Nikkei Peruvians? A statistical analysis of employment status was performed using six relevant variables from the ethnographic study: gender, civil status, place of birth, age group, study status, and social aid. Table (1) showed that there were significant differences between factory and non-factory workers. In particular, the Chi-square test showed that the main differences between these two groups had to do with their civil status, age group, study status, and social aid. On the other hand, differences in gender and place of birth did not (significantly) explain differences in employment status.

The results also showed that some group of Nikkei second generation had the intention to continue tertiary 
education going to the technical career or going to the university. But some of them could not finish high school because of their low grade, bullying or economic problems. Therefore, these people are divided in two groups; one decided to work in the factories as their parents, and the other one who do not work in the factory are working as "ARUBAITO", "FLETEER "or as "HAKENSAHIAIN" in small jobs. These kinds of jobs need the Japanese ability as they already acquired while living in Japan even in different levels. Therefore, they do not continue looking for better academic level even they have the ability in Japanese language. As a consequence their salary will not increase for their future. Most of them are thinking in their present earning but they do not think so seriously that the difference between people who had tertiary education and who do not have it. Because, people in Japan working in the same place and doing the same job can obtain different salaries regarding to their academic background at the Japanese companies.

Unlike the first generation, who's main characteristics was unskilled workers, second generation challenged to be involved in other types of employment status (Shain, Keiyakushain, Hakenshain, arubaito) due to their Japanese ability even in different levels, some of them are continue working at the factories. But their types of contract (Shain, Keiyakushain) at the Japanese company differ from the first generation (Only Hakenshain in most of them). Therefore, the Japanese ability of second generation also is helping them to improve their employment status and to increase their social networking in Japanese society. Then, their decision to stay in Japan (according to the interview), are helping them to see Japan as a country for settlement, having their own family in Japan.

Nikkei Peruvian second generation has significant characteristics as a human and social capital but without the support of their own family to push them to obtain a better academic level, their human capital and social capital as a bridge of two cultures will be devalued. Further research might explore more deeply this problem. Important conclusions drawn from this work include that during the Lehman Shock, some Nikkei Peruvian second generation took advantage learning technical career offered by Japanese government for unemployment people. The crisis and the aid policy of Japanese government during and after the crisis push them to improve their knowledge and as a consequence to improve their employment status for some of them.

\section{References}

Aichi International Association. (2015). Aichi Handbook. Aichi: Ando Printing.

Blade, D., \& Murphy, S. (2008). Transcultural Japan: At the borderlands of race, gender, and identity. New York: Routledge.

Borjas, G. (1999). Economic Research on the Determinants of Immigration. Lesson for the European Union. Washington, D.C: The World Bank. http://dx.doi.org/10.1596/0-8213-4504-4

Brody, B. (2002). Opening the Doors: Immigration, Ethnicity, and Globalization in Japan. New York: Routledge.

Cornelius, A., Tsuda, T., \& Valdez, Z. (2003). Human Capital versus Social Capital. A Comparative Analysis of Immigrant Wages and Labor Market, Incorporation in Japan and the United States. International Migration, 2(1), 5-35.

Goodman, R., Peach, C., Takenaka, A., \& White, P. (2003). Global Japan. The experience of Japan's new immigrants and overseas communities. New York: Routledge.

Hiroshi, I., \& Slater, D. (2009). Social Class in Contemporary Japan: Structures, Socialization and Strategies. New York: Routledge.

Karsten, P. (2010). Peruvians Dispersed, A global Ethnography of Migration. United Kingdom. Rowman \& Littlefield Publishing Group, Inc.

Kondo, A. (2008). Migration and Globalization. New Challenges for Managing Immigration in Japan and Comparison with Western Countries. Tokyo: Akashi Shoten.

Lai, A., Francis, C., \& Brenda, S. A. Y. (2013). Migration and Diversity in Asian Contexts. Approaching Migration and Diversity in Asian Contexts. Pasir Panjang: ISEAS.

Moorehead, R. (2014). Oral Presentation, International Relations, mimeo. Ritsumeikan University.

Mori, H. (1996). Foreign workers working and living condition in Japan. Journal of International Economic Studies, 10, 23-63.

Stanlaw, J. (2004). Japan. Immigration In, Out, and Back and Forth. London: Greenwood Press.

Takashi, M. (2000). Japan and Global Migration. Local settlement patterns of foreign workers in Greater Tokyo. 
New York: Routledge.

Takenaka, A. (2009). How Ethnic Minorities Experience Social Mobility in Japan: An Ethnographic Study of Peruvian Migrants. Researching Social class in Japan, 221-238.

Tanno, K. (2010). The Economic Crisis and Foreign Workers in Japan: Why Does Japan Treat Migrant Workers as Second Class Citizens? Japan Labor Review, 7(3), 109-126.

Yamanaka, K. (1993). New Immigration Policy and Unskilled Foreign Workers in Japan. Pacific Affairs, 66(1), 72-90. http://dx.doi.org/10.2307/2760016

Yamanaka, K. (1999). Labor migration and circular diaspora formation by Japanese Brazilians in Japan. London: Routledge.

Yamashiro, J. (2008). Encyclopedia of Race, Ethnicity, and Society. SAGE publications, Inc. http://dx.doi.org/10.4135/9781412963879

Yoshikawa, H. (2008). Beyond the Family: Contexts of Immigrant Children's Development. San Francisco: Willey Company.

\section{Copyrights}

Copyright for this article is retained by the author (s), with first publication rights granted to the journal.

This is an open-access article distributed under the terms and conditions of the Creative Commons Attribution license (http://creativecommons.org/licenses/by/3.0/). 